\title{
Lypsylehmien maidon juoksettumattomuutta aiheuttavien geenien paikantaminen valituissa kromosomeissa
}

\author{
Anna-Maria Tyrisevä, Kari Elo, Arja Kuusipuro, Veijo Vilva, Nanna Anttila ja Matti Ojala
}

Kotieläintieteen laitos, Koetilantie 5, 00014 Helsingin yliopisto, kari.elo@helsinki.fi

Suomen ayrshirelehmistä $10 \%$ tuottaa maitoa, joka ei juoksetu lainkaan standarditestillä mitattuna. Tällainen maito ei saostu lainkaan juoksetteen lisäyksen jälkeen ja on siten huonoa raaka-ainetta juustomeijereille. Meijeriteknologiset keinot juoksettumattomien maitojen juoksettumiskyvyn palauttamiseksi ovat rajalliset. Myöskään lypsylehmien ruokinnalla ja hoidolla ei pystytä vaikuttamaan maidon juoksettumattomuuteen. Helsingin yliopiston kotieläintieteen laitoksella aiemmin tehtyjen tutkimusten mukaan juoksettumattomuus johtuukin pitkälti geneettisistä tekijöistä. Tämän tutkimushankkeen päätavoitteena oli maidon juoksettumattomuuteen vaikuttavien geenien kartoittaminen. Maidon juoksettumattomuutta (non-coagulating, NC) aiheuttavia kromosomialueita paikannettiin sekä hienokartoitettiin ayrshirellä. Kartoituksessa käytettiin mikrosatelliittimerkkejä. Merkkien kokonaislukumäärä karkeakartoitusvaiheessa oli 194. Merkkien keskimääräinen tiheys oli noin $15 \mathrm{cM}$ ja suurimmat etäisyydet olivat noin $30-40 \quad \mathrm{cM}$. Kromosomit valittiin yksittäisgenotyyppaukseen ja kytkentäanalyyseihin karkeakartoituksen tulosten perusteella. Se tehtiin yhdistämällä eri yksilöiden DNA-näytteitä DNA-seoksiksi. Yli aineiston muodostettiin kaksi DNAseosta: juoksettumatonta maitoa tuottavien eläinten DNA-seos (NC-pooli) ja erittäin hyvin juoksettuvaa maitoa tuottavien eläinten DNA-seos (E-pooli). Jatkoon valikoitui 16 DNA-merkkiä 11 kromosomista (kromosomit 2, 4, 5, 13, 15, 16, 18, 19, 21, 24 ja 27). Yksittäisgenotyyppaukseen valittiin 40 DNAmerkkiä, siten että kromosomialuetta kohti oli kolme merkkiä. Merkkien keskinäinen etäisyys oli 2 -18 cM. Mukana genotyyppauksessa oli 18 perhettä ja aineistokoko oli vajaa 500 lehmää. Aineistosta löytyi useita sekä juoksettumiskyvyn ns. kvantitatiivisen ominaisuuden lokuksia (QTL:iä) että juoksettumattomuuteen vaikuttavia lokuksia. Suurimman uskottavuuden -menetelmällä löytyi vähemmän QTL:liä kuin parametrittomalla menetelmällä. Yli perheiden analysoituna kromosomin 18 tulos saavutti tutkimuskohtaisen $0,1 \%$ :n merkitsevyystason. Kromosomissa 2 yksikään perhe ei saavuttanut parametrittomalla menetelmällä tutkimuskohtaista $10 \%$ :n merkitsevyystasoa, vaikka useilla perheillä oli selvä maksimi samoissa kohdissa. Sen sijaan yli perheiden tulos saavutti tutkimuskohtaisen $0,1 \%$ :n merkitsevyystason.

Asiasanat: maidon juoksettumattomuus, QTL-kartoitus, lypsykarja 


\section{Johdanto}

Suomen ayrshirelehmistä $10 \%$ tuottaa juoksettumatonta ja $30 \%$ huonosti juoksettuvaa maitoa. Juoksettumaton ja huonosti juoksettuva maito ovat huonoa raaka-ainetta juustomeijereille. Noin $40 \%$ eläinten välisistä eroista juoksettumiskyvyssä johtuu perintötekijöistä, joten periaatteessa sitä voisi jalostaa suoran valinnan avulla (Ikonen ym. 2004). Ongelmana on, ettei riittävän tehokasta ja automatisoitua, suurten karjantarkkailuaineistojen analysointiin soveltuvaa mittauslaitetta ole vielä kehitetty. Koska juoksettumiskyvyn suora jalostus ei ole tällä hetkellä mahdollista, kotieläintieteen laitoksella on tutkittu epäsuoria jalostuskeinoja. Näitä ovat maidon juoksettumiskykyyn edullisesti vaikuttavan kappa-kaseiinin B-alleelin suosiminen tai haitallisesti juoksettumiskykyyn vaikuttavan Ealleelin karsiminen (Ikonen 2000), juoksettumiskyvyn geneettisten yhteyksien selvittäminen sonnien kokonaisjalostusarvossa jo mukana oleviin ominaisuuksiin sekä muiden juoksettumiskykyyn voimakkaasti geneettisesti yhteydessä olevien ja helposti mitattavien ominaisuuksien hyödyntäminen (Ikonen ym. 2004). Meijeriteknologisia keinoja huonosti juoksettuvan tai juoksettumattoman maidon juoksettumiskyvyn palauttamiseksi on olemassa, mutta ne ovat rajallisia. Myöskään lypsylehmien ruokinnalla ja hoidolla ei pystytä vaikuttamaan maidon juoksettumattomuuteen. Helsingin yliopiston kotieläintieteen laitoksella tehtyjen tutkimusten mukaan juoksettumattomuus johtuukin pitkälti geneettisistä tekijöistä (Ikonen ym. 2004). Tämän tutkimuksen ensisijaisena tavoitteena on ollut maidon juoksettumattomuuteen vaikuttavien kromosomialueiden kartoittaminen ayrshirella.

\section{Aineisto ja menetelmät}

Tutkimuksen ensimmäiseen eli karkeakartoitusvaiheeseen valittiin sonneja, joilla oli suuri määrä tyttäriä $(>100)$ ja joiden oletettiin olevan heterotsygootteja juoksettumattomuutta aiheuttavan geenin tai geenien suhteen. Sonnien luokittelu heterotsygooteiksi ja homotsygooteiksi perustui niiden tyttäriltä mitattuun maidon juoksettumiskyvyn jakaumaan (Kuva 1). Kuvassa 1 sonni A oletetaan homotsygootiksi juoksettumattomuutta aiheuttavien alleelien suhteen, sonni B oletetaan heterotsygootiksi ja sonni C homotsygootiksi alleelien suhteen jotka eivät vaikuta maidon juoksettumattomuuteen.

Kuva 1. Kolmen sonnin, A, B ja C, tytärten maidon juoksettumiskyvyn jakaumat. Suluissa tytärten lukumäärä. Kuvassa $\mathrm{X}$-akselilla on juoksettuman kiinteys puoli tuntia juoksetteen lisäämiseen jälkeen (mm) ja y-akselilla tytärten mittaustulosten jakautuminen (\%) eri luokkiin. Sonnien A, B ja C tyttäristä noin $45 \%, 13 \%$ ja $2 \%$ lypsää juoksettumatonta maitoa.
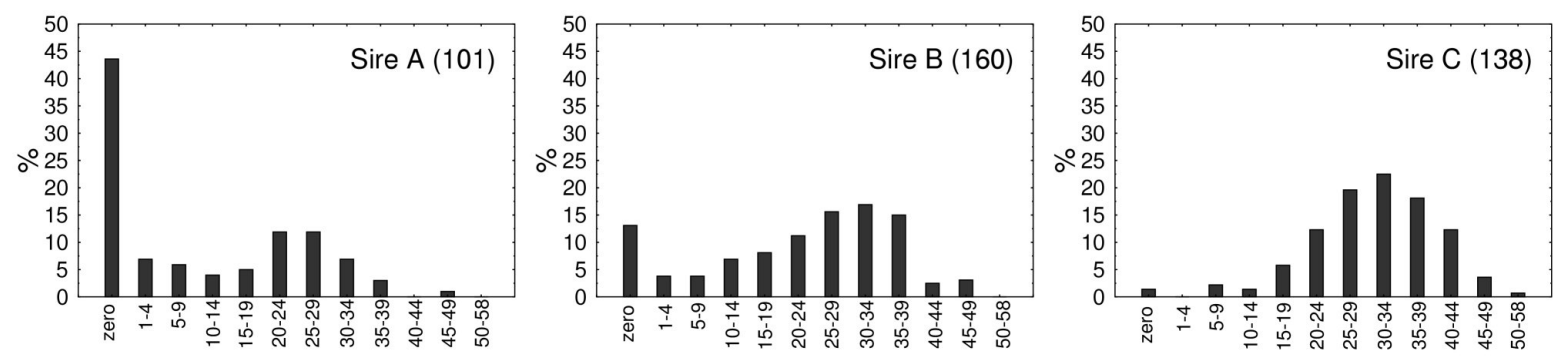

Karkeakartoitus toteutettiin yhdistämällä juoksettumatonta maitoa lypsävien (NC) lehmien ja hyvin juoksettuvaa maitoa lypsävien (E) lehmien DNA-näytteet omiksi seoksikseen (NC- ja E-seos). NC- ja E-seosten alleeli-intensiteeteista korjattiin DNA:n virheellisestä monistumisesta (pienten ja isojen alleelien monistumisero sekä haamumonistuminen) johtuvat virheet. Kullekin DNA-merkille laskettiin yksilöaineiston perusteella korjauskertoimet. Poolien korjatut merkkikohtaiset alleeli-intensiteetit tutkittiin homogeenisyystestillä $\left(\chi^{2}\right)$ poolien välisten intensiteettierojen paljastamiseksi. Tähän käytettiin Sham \& Curtisin (1995) esittämää menetelmää sekä CLUMP-ohjelmistopakettia. Tilastollinen merkitsevyys testattiin simuloimalla testisuureen jakauma Monte Carlo-menetelmällä, sillä aineistot, joissa on paljon harvalukuisia luokkia eivät noudata $\chi^{2}$-jakaumaa. Merkkien kokonaislukumäärä karkeakartoitusvaiheessa oli 194, näistä 10 jouduttiin hylkäämään. Merkit kattoivat koko genomin 
varsin hyvin, keskimääräinen merkkitiheys oli noin $15 \mathrm{cM}$. Suurimmat etäisyydet olivat noin $30-40 \mathrm{cM}$ (6 kohtaa). Tavoitteena oli tehdä 130 merkille haamu- ja monistumiserokorjaus sekä $\chi^{2}$-testi. Esivalinnan perusteina olivat poolien väliset vähäisetkin intensiteettierot visuaalisesti tarkasteltuina tai kromosomin erityinen kiinnostavuus. Aiotuista 130 merkistä pystyttiin testaamaan $92 \%$, loput oli mahdollista tarkastella vain visuaalisesti. Jatkoon pääsyn perusteena oli nollahypoteesin hylkääminen maksimissaan $1 \%$ :n riskitasolla. Tulokset olivat varsin yhdenmukaisia visuaalisen tarkastelun tulosten kanssa. Jatkoon valikoitui 16 DNA-merkkiä 11 kromosomista (kromosomit 2, 4, 5, 13, 15, 16, 18, 19, 21,24 ja 27).

Tutkimuksen toisessa eli hienokartoitusvaiheessa genotyypitettiin yksittäisiä eläimiä karkeakartoitusvaiheessa valituilla kromosomialueilla.. Mukana genotyyppauksessa oli 18 perhettä ja 477 lehmää.Yksittäisgenotyyppaukseen valittiin 40 DNA-merkkiä, 3 merkkiä kromosomialuetta kohti. Merkkien keskinäinen etäisyys oli $2-18 \mathrm{cM}$. Puolisisarten määrä perheittäin vaihteli välillä $14-72 \mathrm{ja}$ puolisisarten kokonaismäärä kasvoi 498:aan. Kaikkien huonosti muuntelevien DNA-merkkien viereen valittiin uudet, muuntelevat DNA-merkit. Muuttujana aineiston analysoinnissa käytettiin systemaattisten ympäristötekijöiden (lypsykauden vaihe, poikimakerta, juoksettumislaitteen anturi, maitonäytteen ikä ja karja) suhteen korjattuja juoksettuman kiinteyden arvoja. Tilastollinen analysointi tehtiin sekä suurimman uskottavuuden menetelmällä käyttäen Animap-ohjelmistoa (Georges ym. 1995) että HSQM-ohjelmiston parametrittomalla menetelmällä (Coppieters ym. 1998)

Tilastollisiin analyyseihin otettiin mukaan jokaisesta perheestä myös juoksettumiskyvyltään keskinkertaiset yksilöt, joilta oli käytettävissä vain fenotyyppitulos. Tällaisten yksilöiden mukaanotto lisää Darvasin ja Sollerin (1992) mukaan tilastollisen testauksen voimaa. Tämä näkyi hyvin, kun aiemmin tutkitut kromosomit 24 ja 28 analysoitiin uudelleen siten, että isien juoksettumiskyvyltään keskinkertaisetkin tyttäret olivat mukana. HSQM:n parametrittoman menetelmän -log (p)-arvo nousi noin 2 yksikköä ja tulos saavutti tutkimuskohtaisen $0.1 \%$ :n merkitsevyystason verrattuna aiempaan (Elo ym. 2007) tulokseen, jossa merkitsevyystaso oli $5 \%$. Genotyypattavat tyttäret edustivat noin 12 $\%$ fenotyyppisen jakauman molemmista ääripäistä. Keskimäärin $70 \%: 1 l e$ genotyypattavista tyttäristä saatiin genotyyppi, merkkikohtainen vaihtelu oli välillä $52-80 \%$.

\section{Tulokset ja tulosten tarkastelu}

Aineistosta löytyi sekä juoksettumiskykyyn vaikuttavia QTL:iä että juoksettumattomuuteen vaikuttavia kromosomialueita. Suurimman uskottavuuden menetelmällä löytyi vähemmän QTL:iä kuin parametrittomalla menetelmällä. Tämä voi johtua siitä, ettei tutkittava muuttuja noudata täysin normaalijakaumaa. Aineiston äärifenotyypit vaikuttavat voimakkaasti jäännösvarianssiin, jolloin QTLvarianssin suhde jäännösvarianssiin pienenee ja tilastollisen testauksen voima heikkenee. Parametrittomassa menetelmässä käytetään fenotyyppien sijasta fenotyyppien sijalukuja, jolloin äärifenotyyppien vaikutus tulokseen ei ole niin voimakas ja menetelmä on sen takia tehokkaampi (Coppieters ym. 1998, Kruglyak \& Lander 1998). Monessa tapauksessa parametrittomalla menetelmällä näkyvä tilastollisesti merkitsevä vaikutus oli nähtävissä myös suurimman uskottavuuden menetelmällä, mutta tulos ei saavuttanut tutkimuskohtaista $10 \%$ :n riskitasoa. Parametrittoman menetelmän puutteena on kuitenkin, ettei QTL:lien vaikutuksien suuruutta pystytä arvioimaan.

Kromosomissa 18 usealla sonnilla oli vain yksi informatiivinen merkki, jolloin Animapohjelmiston perustana oleva intervallikartoitus ei toimi enää tarkoituksenmukaisella tavalla. Tulosten perusteella kromosomista näyttää kuitenkin löytyvän varsin suurivaikutteinen QTL, joka Animapohjelmiston yhden QTL-perheen perusteella olisi juoksettumattomuuteen vaikuttava (Taulukko 1). Yli perheiden analysoituna kromosomin 18 tulos saavutti tutkimuskohtaisen $0.1 \%$ :n merkitsevyystason . Kromosomissa 2 yksikään perhe ei saavuttanut parametrittomalla menetelmällä tutkimuskohtaista 10 \%:n merkitsevyystasoa, vaikka useilla perheillä oli selvä maksimi samoissa kohdissa. Sen sijaan yli perheiden tulos saavutti tutkimuskohtaisen $0.1 \%$ :n merkitsevyystason. Löydettyjen QTL:lien vaikutukset ovat voimakkaita (Taulukko 1.), lähes kahden fenotyyppisen hajonnanyksikön suuruisia. Toisaalta aineiston pienestä koosta johtuen ei voi edes olettaa, että siitä löytyisi vaikutuksiltaan pieniä QTL:liä. 
Taulukko 1. Suurimman uskottavuuden menetelmällä löydetyt perhekohtaiset maidon juoksettumiskykyyn (MCA) ja juoksettumattomuuteen (NC) liittyvät kromosomialueet ja niiden vaikutusten suuruudet. LOD:n arvoille tilastolliset merkitsevyydet on ilmoitettu tutkimuskohtaisesti (engl. experimentwise significance).

\begin{tabular}{cccccccc}
\hline Perhe & Krom & LOD & $\begin{array}{c}\text { LOD:n } \\
\text { maksimikohdan } \\
\text { lähin } \\
\text { mikrosatelliitti }\end{array}$ & $\begin{array}{c}\text { QTL:n } \\
\text { vaikutus }\end{array}$ & $\begin{array}{c}\text { QTL:n } \\
\text { vaikutuksen } \\
\text { SE }\end{array}$ & $\begin{array}{c}\text { QTL-vaikutus/ } \\
\text { fenotyyppinen SD }\end{array}$ & $\begin{array}{c}\text { Alleelin } \\
\text { vaikutuksen } \\
\text { luonne }\end{array}$ \\
\hline 38451 & 16 & $4,5^{* * *}$ & $\begin{array}{c}\text { INRA48-MB103 } \\
\text { 3 }\end{array}$ & $-2,70$ & 0,4 & $-1,9$ & MCA \\
38588 & 16 & $3,3^{* *}$ & INRA48-MB103 & $-2,52$ & 0,7 & $-1,7$ & MCA \\
38651 & 18 & $2,7^{*}$ & BMS1355 & 2,62 & 0,7 & 1,9 & NC \\
38651 & 24 & $4,2^{* *}$ & BM7151 & 2,65 & 0,3 & 1,8 & NC \\
\hline
\end{tabular}

\section{Johtopäätökset}

Tutkimuksessa pystyttiin rajaamaan kaksi lyhyttä kromosomialuetta kromosomeista 2 ja 18 , joiden jatkotutkimus voisi johtaa juoksettumattomuutta aiheuttavien suurivaikutteisten geenien löytymiseen ayrshirellä. Lisäksi kromosomista 24 löytyi yhdestä perheestä maidon juoksettumattomuuteen vaikuttava kromosomialue. Mikäli juoksettumattomuutta aiheuttava geeni tai geenit pystytään tunnistamaan, tietoa voidaan hyödyntää lypsykarjan jalostusvalinnassa. Juoksettumattomuutta aiheuttavien alleelien kantajasonnien karsiminen jalostuksesta parantaisi koko lypsykarjapopulaation maidon juoksettumiskykyä. Juoksettumatonta maitoa lypsävien lehmien poistuminen lypsykarjapopulaatiosta hyödyttäisi suoraan meijeriteollisuutta, joka yhä suuremmassa määrin käyttää tuottajilta ostamansa maidon juustonvalmistuksessa. Tutkimuksessa löytyi myöskin maidon juoksettumiskykyyn vaikuttavia kromosomialueita. Juoksettumiskykyyn liittyvien löytöjen käyttökelpoisuus lypsykarjan jalostusvalinnassa ei kuitenkaan ole yhtä selkeä kuin maidon juoksettumattomuuteen liittyvillä löydöillä.

\section{Kirjallisuus}

Coppieters, W., Kvasz, A., Farnir, F., Arranz, J.-J., Grisart, B., Mackinnon, M., \& Georges, M. 1998. A rank-based nonparametric method for mapping quantitative trait loci in outbred half-sib pedigrees: Application to milk production in a granddaughter design. Genetics 149: 1547-1555.

Darvasi, A., \& Soller, M. 1992. Selective genotyping for determination of linkage between a marker locus and a quantitative trait locus. Theoretical and Applied Genetics 85: 353-359.

Elo, K., Tyrisevä, A.-M., Anttila, P., Vilva, V. \& Ojala, M. 2007. Genomic mapping of non-coagulation of milk in the Finnish Ayrshire. Journal of Animal and Feed Sciences 16: 195-199.

Georges, M., Nielsen, D., Mackinnon, M., Mishra, A., Okimoto, R., Pasquino, A.T., Sargeant, L.S., Sorensen, A., Steele, M.R., Zhao, X., Womack, J.E., \& Hoeschele, I. 1995. Mapping quantitative trait loci controlling milk production in dairy cattle by exploiting progeny testing. Genetics 139: 907-920.

Ikonen, T. 2000. Possibilities of genetic improvement of milk coagulation properties of dairy cows. Väitöskirja. Helsingin yliopisto. Saatavissa osoitteessa: http://ethesis.helsinki.fi/julkaisut/maa/kotie/vk/ikonen

Ikonen, T., Morri, S., Tyrisevä, A.-M., Ruottinen, O., \& Ojala, M. 2004. Genetic and phenotypic correlations between milk coagulation properties, milk production traits, somatic cell count, casein content, and $\mathrm{pH}$ of milk. Journal of Dairy Science 87: 458-467.

Kruglyak, L., \& Lander, E.S. 1995. A nonparametric approach for mapping quantitative trait loci. Genetics 139: 1421-1428.

Sham, P. C., \& Curtis, D. 1995. Monte Carlo tests for associations between disease and alleles at highly polymorphic loci. Ann. Hum. Genet. 59: 97-105. 